Jurnal ECOTIPE, Vol. 8, No.1, April 2021, Hal. 39-46

p-ISSN 2355-5068, e-ISSN 2622-4852

Akreditasi Kemenristekdikti (SINTA 4), SK. No.10/E/KPT/2019

DOI: 10.33019/jurnalecotipe.v8i1.2121

\title{
Pemanfaatan Logika Fuzzy sebagai Pengendali Steering pada Hardware In the Loop Mobil Listrik Otomatis
}

\author{
Caroline ${ }^{1}$, Rudyanto Thayeb ${ }^{2}$, Hermawati ${ }^{3}$, Wirawan Dwi Harsanto ${ }^{4}$, \\ Suci Dwijayanti ${ }^{5}$, Bhakti Yudho Suprapto ${ }^{6}$ \\ Jurusan Teknik Elektro, Fakultas Teknik, Universitas Sriwijaya ${ }^{1,2,3,4,5,6}$ \\ *bhakti@ft.unsri.ac.id
}

\begin{abstract}
A car is a necessity and a means of transportation that makes it easy to travel. Many types and products of cars have been developed now, one of which is electric cars because fossil fuels have started to deplete in availability. The next development is an autonomous electric car. However, autonomous control systems such as steering and speed control are complex and difficult tasks that require optimal, precise, and robust control systems. Therefore, in this paper, a control system using the fuzzy logic method is developed by utilizing input from the Ultrasonic sensor. This sensor is capable of detecting objects with the farthest distance of 10 meters and crunching 0.3 meters. The output of this control system is the degree of rotation of the steer on the Hardware In The Loop which can turn to avoid the object being detected. Based on this system test, the accuracy of the degree of rotation of the steer is $5^{\circ}$ and the maximum rotation is $30^{\circ}$, while the top speed of the rear wheels is $15 \mathrm{~km}$ / h. The steering system on the Hardware In The Loop has pretty good accuracy about 97,9\% to improve smoothness when turning.
\end{abstract}

Keywords : Fuzzy Logic, Autonomous Electric Vehicle, Hardware In The Loop, Ultrasonic Maxbotix, Object Detection

\section{INTISARI}

Mobil merupakan sebuah kebutuhan dan alat transportasi yang memudahkan dalam berpergian. Banyak jenis dan produk mobil yang telah dikembangkan sekarang, salah satunya adalah mobil listrik dikarenakan bahan bakar minyak fosil sudah mulai menipis ketersediaannya. Pengembangan berikutnya adalah mobil listrik yang otomatis. Namun sistem kontrol otomatis seperti kemudi (steering) dan kontrol kecepatan adalah tugas kompleks serta sulit sehingga memerlukan sistem kendali yang tepat, presisi dan kuat. Oleh karena itu pada paper ini dikembangkan suatu sistem kendali yang menggunakan metode logika fuzzy dengan memanfaatkan input dari sensor ultrasonik. Sensor ini mampu mendeteksi objek dengan jarak terjauh sebesar 10 meter dan terderak 0,3 meter, keluaran dari sistem kendali ini adalah derajat putar steer pada Hardware In the Loop yang dapat berbelok menghindari objek terdeteksi. Berdasarkan pengujian sistem ini, ketelitian derajat putar steer adalah $5^{\circ}$ dan putaran maksimalnya adalah $30^{\circ}$, sedangkan untuk kecepatan tertinggi roda belakang adalah $15 \mathrm{~km} / \mathrm{jam}$. Sistem steering pada Hardware In the Loop ini memiliki ketelitian yang cukup bagus yaitu 97,9\% dan untuk meningkatkan kehalusan (smoothness) ketika berbelok.

Kata kunci: Logika Fuzzy, Auotonomous Electric Vehicle, Hardware In the Loop, Ultrasonic Maxbotix, Deteksi Objek

\section{PENDAHULUAN}

Salah satu sarana transportasi yang banyak digunakan saat ini yaitu mobil. Saat ini mobil telah menjadi kebutuhan bagi orang-orang karena begitu banyaknya kegunaan mobil tersebut. Namun mengingat makin berkurangnya minyak bumi yang digunakan sebagai bahan bakar, banyak peneliti mulai melirik jenis bahan bakar lain. Bahkan mulai mengembangkan jenis kendaraan yang bergerak secara otomatis. Akan tetapi untuk membentuk mobil tersebut menjadi otomatis tentunya sangat sulit dan memerlukan akurasi yang baik khususnya sistem sensor dan sistem kontrol yang kompleks diantaranya adalah seperti sistem kontrol kemudi (steering) dan sistem kontrol kecepatan. Untuk mengatur kecepatan kendaraan dengan perubahan signifikan pada kemudi dan mencapai tujuan dengan mengoptimalkan waktu dan lintasan[1]. Guna mendapatkan sistem kendali 
Jurnal ECOTIPE, Vol. 8, No.1, April 2021, Hal. 39-46

p-ISSN 2355-5068, e-ISSN 2622-4852

Akreditasi Kemenristekdikti (SINTA 4), SK. No.10/E/KPT/2019

DOI: 10.33019/jurnalecotipe.v8i1.2121

yang optimal sebelum diterapkan langsung pada mobil, biasanya diimplementasikan terlebih dahulu pada prototipe dengan perangkat keras yang menyerupai mobil sebenarnya yang dikenal dengan Hardware In the Loop (HIL).

Sistem kontrol pada HIL mobil listrik memiliki prinsip kerja seperti robot penghindar halangan yang menggunakan sensor sebagai acuan dalam menghindari halangan. Pengaplikasian obstacle avoidance robot mendapatkan masukan sistem dari sensor ultrasonic untuk menghasilkan gerakan menuju ke sasaran yang diinginkan. Pada obstacle avoidance robot [2] tersebut, masukan yang didapat dari sensor akan menjadi acuan bagi robot dalam bergerak ke depan sehingga apabila terdapat halangan didepannya maka pengendali robot tersebut memerintahkan motor penggerak roda untuk bergerak menghindar ke kanan atau ke kiri. Masukan sistem ini dapat juga menggunakan sebuah kamera sebagai sensor pada obstacle avoidance robot. Fungsi yang sama diharapkan dapat diterapkan pada HIL untuk memudahkan kinerja dari sistem kontrol pada steering mobil listrik dan mampu bekerja secara optimal saat diaplikasikan secara langsung. Misi yang dilakukan pada kontrol steering HIL mobil listrik ini adalah menghindari sebuah halangan atau berbelok dengan optimal dan secara halus (smooth) dengan bergerak secara autonoumus.

Beberapa metode sistem kontrol otomatis yang digunakan untuk kontrol steering dan kecepatan mobil listrik diantaranya adalah Proportional Integral Derivative (PID), Fuzzy + PID dan lain-lain[3]. Pada penelitian ini penulis menggunakan metode logika fuzzy. Metode kontrol fuzzy ditujukan untuk meningkatkan stabilitas sumbu yaw kendaraan[4], dalam hal ini adalah stabilas mobil saat berbelok. Pengendali logika fuzzy memiliki efek kontrol yang baik terutama untuk objek dengan sifat non-linier atau objek yang modelnya sangat sulit dibuat secara akurat[5]. Beberapa penelitian menggunakan metode fuzzy ini untuk pengontrolan seperti pada kecepatan motor arus searah[6], pengendalian ketinggian pada quadrotor drone[7][8] dan pengendalian gerakan manipulator robot[9], Untuk meningkatkan kinerja, teori kontrol logika fuzzy diterapkan pada pengembangan algoritma kontrol. Sedangkan PID membawa kelemahan Proporsional, Integral dan Diferensialnya[10]. Penggunaan PID kontroler dalam suatu sistem mempunyai kelemahan, yakni bahwa parameter-parameter dalam kontroler harus selalu diubah (tuned up) bila terjadi perubahan didalam sistem, perubahan tersebut akan menyebabkan terjadinya tuning kembali dari parameter-parameter PID tersebut[6]. Sedangkan pada Logika Fuzzy, parameter ini dibuat dalam range. Sehingga jika ada perubahan maka selama masih dalam range tersebut akan dapat diatasi oleh pengendali ini.

\section{LANDASAN TEORI}

A. Algoritma Logika Fuzzy

Algoritma logika fuzzy dapat mempresentasikan setiap keadaan atau mewakili pemikiran manusia. Dalam logika fuzzy, keanggotaan elemen berada di interval 0 sampai 1 . Logika fuzzy memiliki beberapa komponen yang harus dipahami seperti himpunan fuzzy, fungsi keanggotaan, operator pada himpunan fuzzy, inferensi fuzzy dan defuzzifikasi[11][12].

Sistem fuzzy ini memiliki beberapa keistimewaan, yaitu sistem fuzzy ini cocok digunakan pada sistem pemodelan karena variabelnya bernilai riil, lalu sistem ini menyediakan kerangka yang digunakan untuk menggabungkan aturan-aturan fuzzy jika-maka yang bersumber dari pengalaman manusia. Tahapan sistem fuzzy dapat dilihat pada Gambar 1.

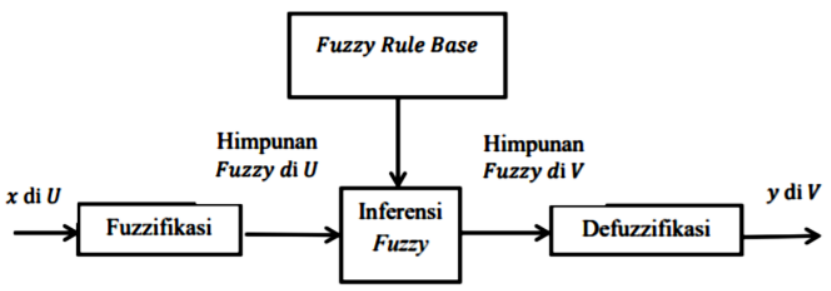

Gambar 1. Susunan sistem fuzzy[13]

Penjelasan dari tahapan sistem fuzzy adalah sebagai berikut:

1. Fuzzifikasi

Fuzzifikasi didefinisikan sebagai pemetaan dari himpunan tegas ke himpunan fuzzy. Kriteria yang harus dipenuhi pada proses fuzzifikasi adalah semua anggota pada himpunan tegas harus termuat dalam himpunan fuzzy.

2. Aturan Fuzzy

Aturan yang digunakan pada himpunan fuzzy adalah aturan if then. Aturan fuzzy IF-THEN merupakan pernyataan yang direpresentasikan.

3. Inferensi Fuzzy 
Jurnal ECOTIPE, Vol. 8, No.1, April 2021, Hal. 39-46

p-ISSN 2355-5068, e-ISSN 2622-4852

Akreditasi Kemenristekdikti (SINTA 4), SK. No.10/E/KPT/2019

DOI: 10.33019/jurnalecotipe.v8i1.2121

Inferensi fuzzy merupakan tahap evaluasi pada aturan fuzzy. Tahap evaluasi dilakukan berdasarkan penalaran dengan menggunakan masukan sistem fuzzy dan aturan fuzzy sehingga diperoleh output berupa himpunan fuzzy[13]. Ada beberapa macam inferensi fuzzy yaitu metode Mamdani, Tsukamoto, dan Sugeno yang sering digunakan.

4. Defuzzifikasi

Definisi defuzzifikasi sebagai pemetaan dari himpunan fuzzy ke himpunan tegas. Himpunan fuzzy yang dimaksud disini adalah hasil output yang diperoleh dari hasil inferensi. Pada proses defuzzifikasi ada tiga kriteria yang harus dipenuhi yaitu masuk akal, perhitungannya sederhana dan kontinu.

Berikut adalah beberapa metode yang digunakan untuk proses defuzzifikasi yaitu metode Centroid, metode Bisektor, Metode Mean of Maximum (MOM), Metode Largest of Maximum (LOM), dan Metode Smallst of Maximum (SOM)[13][14]. Logika fuzzy juga memiliki beberapa metode diantaranya yaitu metode Mamdani, Sugeno, dan Tsukamoto.

\section{a. Metode Fuzzy Mamdani}

Metode fuzzy Mamdani dalam prosesnya menggunakan kaedah-kaedah linguistik dan memiliki algoritma fuzzy yang dapat dianalisis secara matematika, sehingga lebih mudah dipahami. Proses pengambilan keputusan dengan menggunakan Metode fuzzy Mamdani untuk memperoleh keputusan yang terbaik, dilakukan dengan melalui beberapa tahapan, yaitu pembentukan himpunan fuzzy; aplikasi fungsi implikasi; komposisi aturan; defuzzifikasi. Kelebihan pada metode fuzzy mamdani adalah lebih spesifik, artinya dalam prosesnya metode fuzzy mamdani lebih memperhatikan kondisi yang akan terjadi untuk setiap daerah fuzzy nya, sehingga menghasilkan hasil keputusan yang lebih akurat.

secara umum aturan fuzzy memiliki bentuk :

IF $\left(x_{1}=A_{1}\right) A N D\left(x_{2}=A_{2}\right) A N D \ldots . . A N D\left(x_{n}=A_{n}\right)$ THEN $y=B$

b. Metode Fuzzy Sugeno

Metode fuzzy Sugeno merupakan metode inferensi fuzzy untuk aturan yang direpresentasikan dalam bentuk IF -THEN, dimana output (konsekuen) sistem tidak berupa himpunan fuzzy, melainkan berupa konstanta atau persamaan linier. Metode sugeno ini merupakan metode fuzzy yang telah terbukti efektif ketika berhadapan dengan sistem non linier yang kompleks, yang sangat sulit untuk analisisdan sintesis. Pada metode Sugeno, setiap keluaran sistem (konsekuen) terbentuk dari aturan IF-THEN tidak berupa himpunan fuzzy, melainkan konstanta atau persamaan linier.

c. Metode Fuzzy Tzukamoto

Pada dasarnya, metode fuzzy Tsukamoto mengaplikasikan penalaran monoton pada setiap aturannya. Kalau pada penalaran monoton, sistem hanya memiliki satu aturan, pada metode fuzzy Tsukamoto, sistem terdiri atas beberapa aturan. Karena menggunakan konsep dasar penalaran monoton, pada metode fuzzy Tsukamoto, setiap konsekuen pada aturan yang berbentuk IF-THEN harus direpresentasikan dengan suatu himpunan fuzzy dengan fungsi keanggotaan yang monoton. Output hasil inferensi dari tiap-tiap aturan diberikan secara tegas (crisp) bedasarkan $\alpha$-predikat (fire strength). Proses agregasi antar aturan dilakukan, dan hasil akhirnya diperoleh dengan menggunakan defuzzy dengan konsep rata-rata terbobot.

Sistem inferensi fuzzy merupakan suatu kerangka komputasi yang didasarkan pada teori himpunan fuzzy, aturan fuzzy berbentuk IF-THEN, dan penalaran fuzzy. Secara garis besar, diagram blok proses inferensi fuzzy. Diagram blok sistem inferensi fuzzy Tsukamoto dapat dilihat pada Gambar 2.

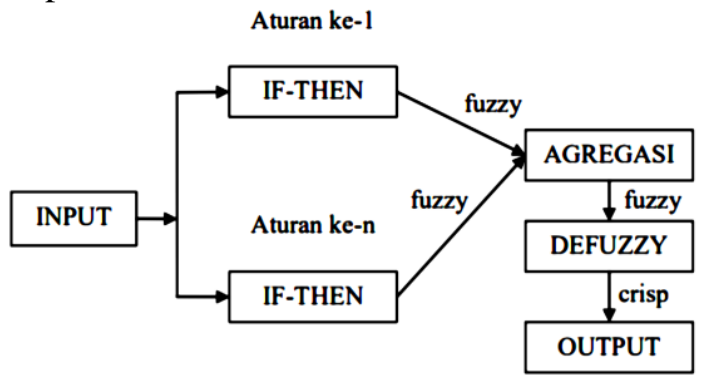

Gambar 2. Sistem inferensi fuzzy Tsukamoto

\section{METODE PENELITIAN}

Penelitian ini dilakukan untuk melakukan kontrol steering pada mobil listrik sehingga memiliki tingkat kehalusan (smoothness) ketika berbelok atau menghindari halangan. Dalam melakukan penelitian ini ada beberapa langkah yang bisa dilihat pada flowchart penelitian seperti pada Gambar 3. Data yang digunakan dalam penelitian ini adalah data yang diambil dari Hardware In the Loop yang telah dilakukan pengujian. penelitian ini mengambil data yang diperlukan yaitu 
Jurnal ECOTIPE, Vol. 8, No.1, April 2021, Hal. 39-46

p-ISSN 2355-5068, e-ISSN 2622-4852

Akreditasi Kemenristekdikti (SINTA 4), SK. No.10/E/KPT/2019

DOI: 10.33019/jurnalecotipe.v8i1.2121

derajat putar dari sistem steering serta kecepatan putaran ban yang bergerak. Teknik pengumpulan data pada penelitian ini adalah dengan melakukan pengujian secara langsung pada HIL. Penelitian ini melakukan pengujian langsung pada HIL. Berikut adalah flowchart sebagai acuan dalam penelitian ini.

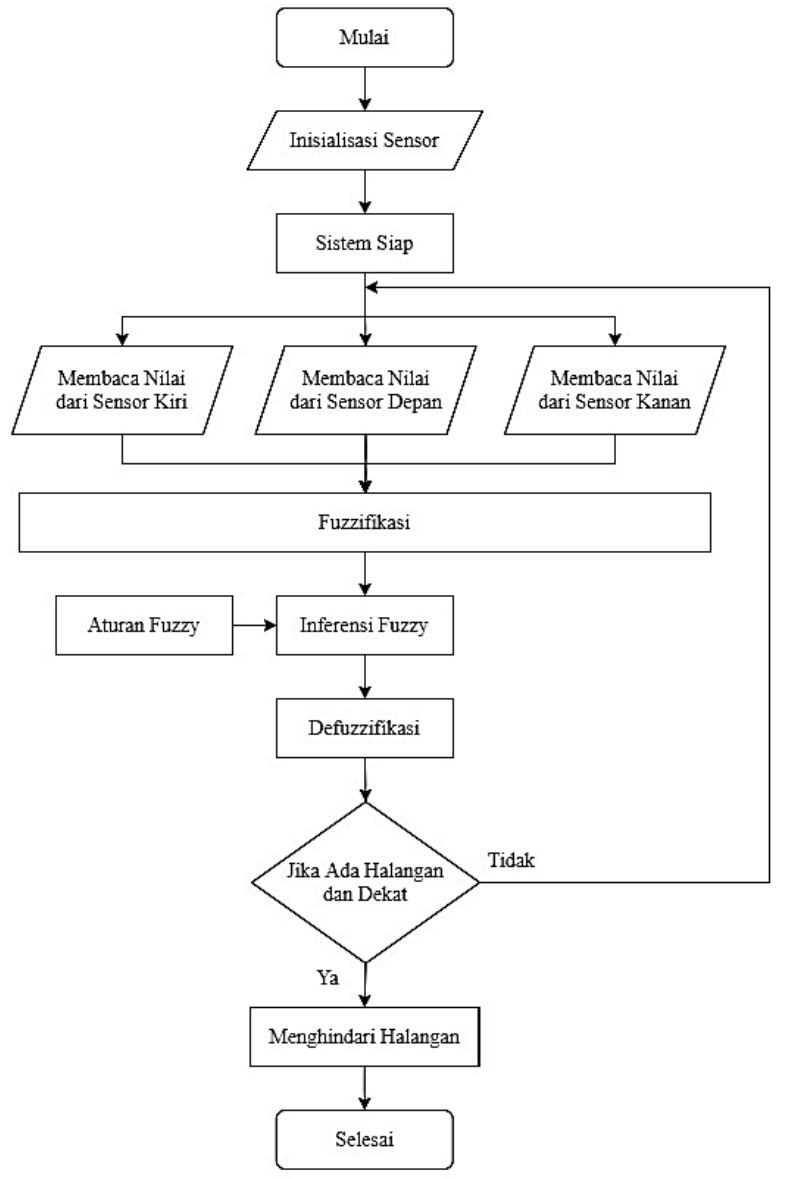

Gambar 3. Perancangan dan simulasi HIL

Pada Gambar 3 merupakan tahapan-tahapan dalam penelitian ini. Sebelum proses pergerakan motor DC ada pemrosesan dari logika fuzzy berdasarkan aturan yang telah penulis tentukan.

Logika fuzzy menunjukkan menjadi tool yang cocok untuk mengatur sesuatu ambigu yang muncul dari hasil yang tidak tepat termasuk pengukuran, proses, model dan ketidakpastian implementasi. dalam melakukan kerjanya, HIL ini memerlukan masukan sistem dari sensor untuk mengukur jarak di sekitar HIL dari hambatan depan, hambatan kiri, dan hambatan kanan. Dari informasi yang diperoleh oleh sensor HIL, aturan kontrol fuzzy yang relevan diaktifkan. Output dari aturan yang diaktifkan dikombinasikan dengan operasi logika fuzzy untuk mengontrol kecepatan dan sudut kemudi dari roda penggerak HIL. Bagian utama dari pengontrol ditunjukkan pada Gambar 4.

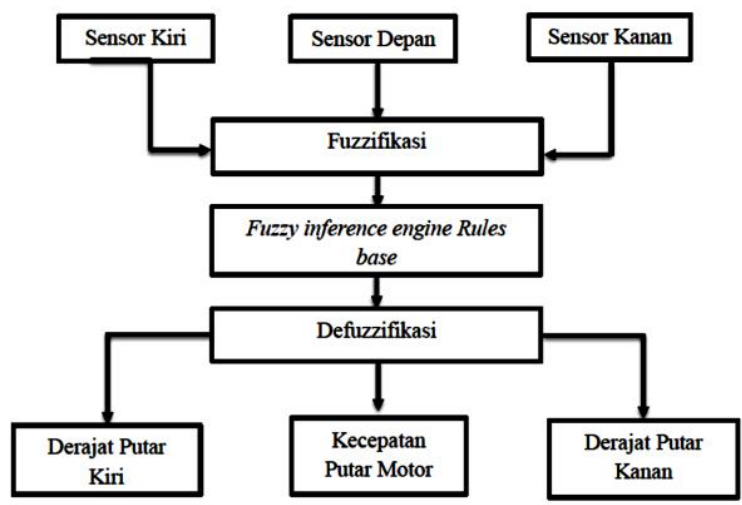

Gambar 4. Arsitektur kontroler fuzzy

Pada proses logika fuzzy, proses yang dilakukan yaitu fuzzifikasi, inferensi fuzzy, aturan fuzzy, dan defuzzifikasi. Proses ini bertujuan untuk mengatur keluaran sistem yaitu motor DC untuk mengatur derajat putar steer dan kecepatan putar roda.

Pada tahap logika fuzzy ini, sensor jarak ultrasonik yang terdapat pada kiri, kanan, dan tengah HIL akan bekerja dengan membaca nilai jarak dari sensor ke suatu objek. Saat sensor bekerja, maka sistem akan masuk kedalam tahapan fuzzifikasi yang berarti pemetaan dari hasil pembacaan sensor menjadi himpunan fuzzy. Kemudian hasil pemetaan tersebut masuk kedalam tahan inferensi fuzzy, yaitu adalah tahap dimana pemetaan itu akan dievaluasi berdasarkan aturan-aturan yang telah dibuat. Kemudian dari hasil evaluasi tersebut dilakukan pemetaan kembali pada tahap defuzzifikasi. Pada tahap ini akan dilakukan pemetaan lagi untuk mengetahui keluaran dari sistem yang dibuat berdasarkan aturan-aturan.

Keluaran dari sistem ini adalah mengatur nilai kecepatan putar dari motor DC pada roda kanan dan roda kiri. Kemudian nilai dari derajat putar steer HIL. Jika terdapat halangan yang dibaca oleh sensor maka robot akan menghindari halangan tersebut, jika tidak ada halangan sistem akan terus looping ke tahapan pembacaan sensor secara terus-menerus. Jika halangan berhasil terhindari maka sistem akan selesai. 
Jurnal ECOTIPE, Vol. 8, No.1, April 2021, Hal. 39-46

p-ISSN 2355-5068, e-ISSN 2622-4852

Akreditasi Kemenristekdikti (SINTA 4), SK. No.10/E/KPT/2019

DOI: 10.33019/jurnalecotipe.v8i1.2121

\section{HASIL PENELITIAN}

\section{A. Perancangan HIL}

Perancangan HIL dilakukan dengan menyiapkan berbagai komponen yang diperlukan oleh perangkat HIL serta mikrokontroler yang digunakan. Perancangan HIL ini terdiri dari perancangan mekanik dan pengkabelan komponen-komponen yang digunakan. Base dari HIL ini menggunakan bahan dasar kayu triplek, kemudian komponen serta sensor dipasang sesuai perancangan yang telah dibuat. Hasil dari perancangan HIL dapat dilihat pada Gambar 5. Gambar 5 ini merupakan HIL yang digunakan untuk pengambilan data, HIL ini memakai 3 sensor jarak ultrasonic maxbotix untuk mengukur jarak objek yang ada 25 di depan HIL. Lalu data jarak benda yang didapat dari pembacaan sensor serta nilai kecepatan roda dan derajat putar akan ditampilkan di LCD.

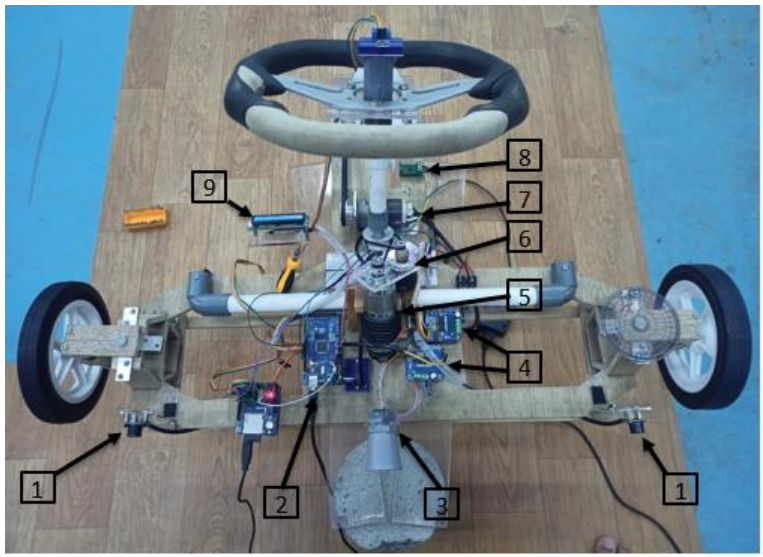

Gambar 5 Hardware In the Loop

Keterangan :

1. Ultrasonic Maxbotix MB1220

2. Arduino Mega 2560

3. Ultrasonic Maxbotix MB7076

4. Motor Driver BTS 7960

5. Motor DC PG45

6. Rotary Encoder

7. Motor DC

8. Hall Magnetic Sensor KY-003

9. LCD I2C $16 \times 2$

\section{B. Pengujian Sistem Fuzzy}

Pada pengujian ini, fuzzy yang digunakan menggunakan 5 kelas fuzzy untuk masukan sensor, yaitu sangat jauh, jauh, sedang, dekat, dan sangat dekat. Dan untuk keluaran derajat putar juga menggunakan 5 kelas fuzzy, yaitu sangat jauh, jauh, sedang, dekat, dan sangat dekat. Untuk keluaran kecepatan roda HIL juga menggunakan 5 kelas fuzzy, yaitu sangat cepat, cepat, sedang, lambat, dan sangat lambat. Sensor yang digunakan adalah sensor Ultrasonic Maxbotic MB1220 dan MB7076, untuk keluaran derajat putar HIL menggunakan Motor DC ditambah Encoder, dan keluaran keceparan roda HIL menggunakan Motor DC dengan sensor Hall Magnetic KY-003 untuk mengukur kecepatan putar roda.

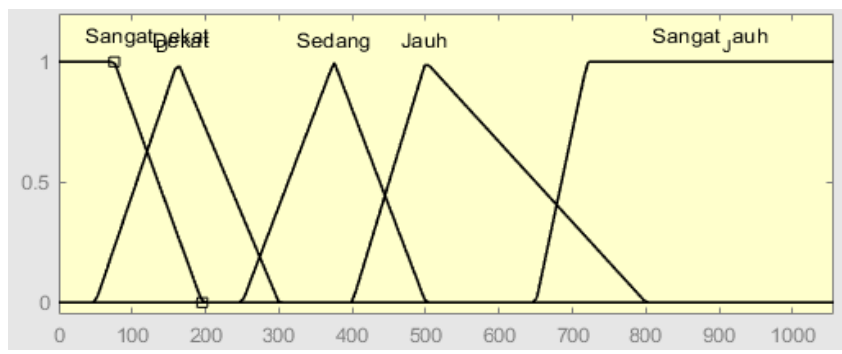

Gambar 6. Kurva baku untuk variabel sensor ultrasonik

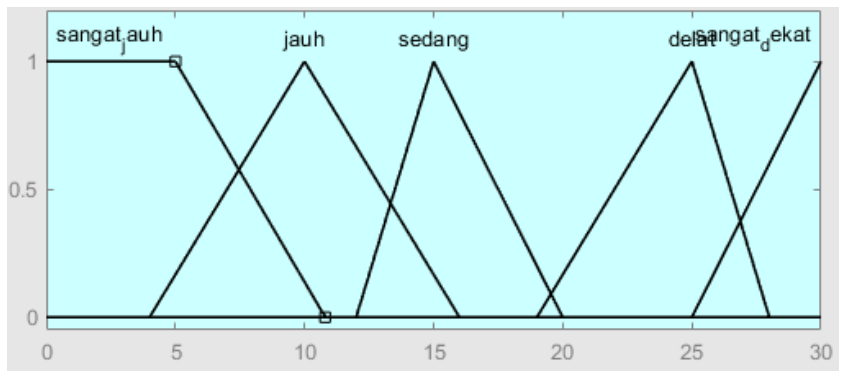

Gambar 7. Kurva baku untuk variabel derajat Steer

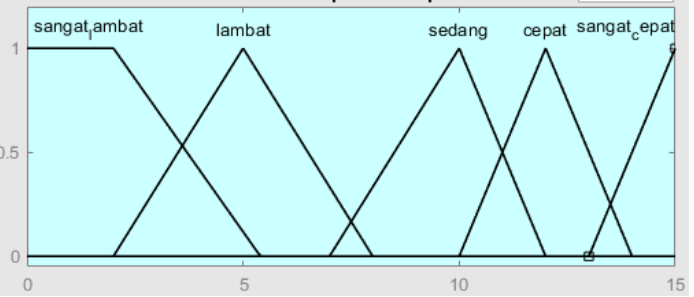

Gambar 8. Kurva baku untuk variabel kecepatan roda HIL

Gambar 6 merupakan Fuzzifikasi untuk mengubah data masukan sensor kedalam bentuk derajat keanggotaan fuzzy. Setelah sistem memberi keputusan yang sesuai dengan aturan fuzzy yang sudah dibuat, maka sistem akan memberi keluaran sistem berupa derajat putar steer dapat dilihat pada Gambar 7 dan kecepatan roda belakang HIL yang dapat dilihat pada Gambar 8. Bila jarak objek semakin dekat dengan HIL maka steer akan berbelok semakin tajam dan kecepatan roda akan semakin pelan sesuai dengan aturan fuzzy yang telah dibuat pada program Arduino IDE. 
Jurnal ECOTIPE, Vol. 8, No.1, April 2021, Hal. 39-46

p-ISSN 2355-5068, e-ISSN 2622-4852

Akreditasi Kemenristekdikti (SINTA 4), SK. No.10/E/KPT/2019

DOI: 10.33019/jurnalecotipe.v8i1.2121

\section{Hasil Pengujian Sistem pada HIL}

Pada tahap ini, langkah yang dilakukan adalah menguji rules fuzzifikasi secara langsung dengan meletakkan HIL pada posisi yang telah ditentukan. Setelah itu, objek yang telah disiapkan akan diletakkan pada jarak dan posisi tertentu. Data derajat putar setir dan kecepatan roda akan diolah dan menentukan presentase keberhasilan. Hasil pengujian tingkat kehalusan (smoothness) pada steering HIL dapat dilihat pada Tabel 1.

Tabel 1. Hasil Pengujian HIL

\begin{tabular}{|l|c|c|c|c|}
\hline \multirow{2}{*}{ No } & \multicolumn{3}{|c|}{ Nilai Sebenarnya } & Derajat \\
\cline { 2 - 4 } & SD $(\mathbf{c m})$ & Ski $(\mathbf{c m})$ & Ska $(\mathbf{c m})$ & 0 \\
\hline 1 & 1000 & 1000 & 1000 & 0 \\
\hline 2 & 700 & 700 & 700 & 0 \\
\hline 3 & 500 & 500 & 500 & 0 \\
\hline 4 & 300 & 300 & 300 & 10 \\
\hline 5 & 500 & 500 & 700 & 25 \\
\hline 6 & 300 & 300 & 700 & 30 \\
\hline 7 & 100 & 100 & 700 & -10 \\
\hline 8 & 500 & 700 & 500 & -25 \\
\hline 9 & 300 & 700 & 300 & -30 \\
\hline 10 & 100 & 700 & 100 & \\
\hline
\end{tabular}

Dapat dilihat pada Tabel 1 bahwa nilai pengukuran jarak dengan sensor Ultrasonic Maxbotix MB1220 dan MB7076 cukup baik karena nilai yang dibaca sensor mendekati nilai jarak sebenarnya dari objek.

Tabel 2. Presentase Keberhasilan

\begin{tabular}{|c|c|c|c|c|c|c|}
\hline \multirow[b]{2}{*}{ No } & \multicolumn{3}{|c|}{ Input Sistem } & \multicolumn{2}{|c|}{ Output Sistem } & \multirow[b]{2}{*}{$\%$} \\
\hline & $\begin{array}{c}\text { Sensor } \\
\text { Kiri }\end{array}$ & $\begin{array}{l}\text { Sensor } \\
\text { Depan }\end{array}$ & $\begin{array}{l}\text { Sensor } \\
\text { Kanan }\end{array}$ & $\begin{array}{c}\text { Derajat } \\
\text { putar } \\
\text { steer }\end{array}$ & $\begin{array}{c}\text { kecepa } \\
\text { tan }\end{array}$ & \\
\hline 1 & $\begin{array}{l}\text { sangat } \\
\text { jauh }\end{array}$ & $\begin{array}{c}\text { sangat } \\
\text { jauh }\end{array}$ & $\begin{array}{c}\text { sangat } \\
\text { jauh }\end{array}$ & $\begin{array}{c}\text { sangat } \\
\text { besar }\end{array}$ & $\begin{array}{c}\text { sangat } \\
\text { cepat }\end{array}$ & 100 \\
\hline 2 & jauh & jauh & jauh & $\begin{array}{l}\text { sangat } \\
\text { besar }\end{array}$ & cepat & 100 \\
\hline 3 & sedang & sedang & sedang & $\begin{array}{c}\text { sangat } \\
\text { besar }\end{array}$ & sedang & 100 \\
\hline 4 & dekat & dekat & dekat & $\begin{array}{l}\text { sangat } \\
\text { besar }\end{array}$ & lambat & 100 \\
\hline 5 & $\begin{array}{c}\text { sangat } \\
\text { dekat }\end{array}$ & $\begin{array}{c}\text { sangat } \\
\text { dekat }\end{array}$ & $\begin{array}{c}\text { sangat } \\
\text { dekat }\end{array}$ & $\begin{array}{l}\text { sangat } \\
\text { besar }\end{array}$ & $\begin{array}{l}\text { sangat } \\
\text { lambat }\end{array}$ & 100 \\
\hline 6 & sedang & sedang & jauh & sedang & sedang & 95 \\
\hline 7 & dekat & dekat & jauh & kecil & lambat & 95 \\
\hline 8 & $\begin{array}{c}\text { sangat } \\
\text { dekat }\end{array}$ & $\begin{array}{c}\text { sangat } \\
\text { dekat }\end{array}$ & jauh & $\begin{array}{c}\text { sangat } \\
\text { kecil }\end{array}$ & $\begin{array}{l}\text { sangat } \\
\text { lambat }\end{array}$ & 100 \\
\hline 9 & jauh & sedang & sedang & sedang & sedang & 90 \\
\hline 10 & jauh & dekat & dekat & kecil & lambat & 95 \\
\hline
\end{tabular}

\begin{tabular}{|c|c|c|c|c|c|c|}
\hline 11 & jauh & $\begin{array}{c}\text { sangat } \\
\text { dekat }\end{array}$ & $\begin{array}{c}\text { sangat } \\
\text { dekat }\end{array}$ & $\begin{array}{c}\text { sangat } \\
\text { kecil }\end{array}$ & $\begin{array}{c}\text { sangat } \\
\text { lambat }\end{array}$ & 100 \\
\hline 12 & $<70 \mathrm{~cm}$ & $<70 \mathrm{~cm}$ & $<70 \mathrm{~cm}$ & $\begin{array}{c}\text { Sangat } \\
\text { kecil }\end{array}$ & stop & 100 \\
\hline
\end{tabular}

Dapat dilihat pada Tabel 2 bahwa presentase keberhasilan sistem steering pada HIL ini cukup baik yaitu sebesar 97,9\%.

Data RPM yang didapatkan menggunakan sensor Hall Magnetic KY-003 belum dikonversi menjadi nilai kecepatan pada HIL ini yang memiliki satuan $\mathrm{Km} / \mathrm{h}$. Oleh karena itu, data RPM ini perlu dikonversi menjadi data kecepatan. Persamaan yamg dibutuhkan untuk mengkonversi data RPM menjadi kecepatan adalah persamaan keliling lingkaran pada persamaan 2 dan rumus rotasi per menit yang dapat dilihat di persamaan 3.

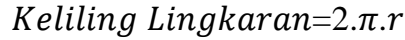 $R P M=n / 60$}

Pada Persamaan 2 nilai phi adalah 3,14 dan $\mathrm{r}$ adalah jari-jari roda HIL. Pada Persamaan 3 nilai $n$ adalah jumlah rotasi roda HIL, dari kedua persamaan tersebut jika digabungkan maka ada menjadi persamaan kecepatan dalam satuan $\mathrm{m} / \mathrm{s}$ yang dapat dilihat pada Persamaan 4. jika satuan $\mathrm{m} / \mathrm{s}$ dikonversi menjadi satuan $\mathrm{km} / \mathrm{h}$ maka persamaan 3 dikalikan dengan 3600 (1 jam sama dengan 3600 detik) lalu dibagi 1000 (1 km sama dengan $1000 \mathrm{~m})$ maka persamaan yang baru dapat dilihat pada Persamaan 5.

$$
\begin{aligned}
& V=2 \cdot \pi \cdot r(n / 60) \\
& V=2 \cdot \pi \cdot r(n / 60) \times(3600 / 1000)
\end{aligned}
$$

Pada penelitian ini digunakan jari-jari sebesar 0,08 $m$ sesuai dengan jari-jari pada roda yang HIL digunakan dalam pengambilan data. Jumlah rotasi yang digunakan akan berbeda tergantung dengan kecepatan roda HIL saat melaju. Jika dilihat pada percobaan pertama pada Tabel 1 didapatkan keluaran sistem berupa kecepatan dengan nilai $15 \mathrm{Km} / \mathrm{h}$. Jika pada saat itu RPM sebesar 498 maka dapat dibuktikan dengan menggunakan Persamaan 2 berikut ini :

$$
\begin{aligned}
& V=2 \times 3,14 \times 0,08 \times \frac{498}{60} \times \frac{3600}{1000} \\
& V=0.5 \times 8.3 \times 3.6=14.94 \approx 15 \mathrm{~km} / \mathrm{jam}
\end{aligned}
$$

Pada nomor 1 sampai 5 merupakan percobaan ketika semua sensor membaca objek yang ada dari jarak 1 meter sampai 10 meter maka keluaran sistem ialah 32 kecepatan putar roda HIL melambat sampai 
Jurnal ECOTIPE, Vol. 8, No.1, April 2021, Hal. 39-46

p-ISSN 2355-5068, e-ISSN 2622-4852

Akreditasi Kemenristekdikti (SINTA 4), SK. No.10/E/KPT/2019

DOI: 10.33019/jurnalecotipe.v8i1.2121

berhenti, hal ini di asumsikan ketika terdapat kendaraan yang sedang melambatkan lajunya atau berhenti. Pada nomor 6 sampai 8 merupakan percobaan ketika sensor depan dan sensor kiri membaca obstacle dari jarak 5 meter sampai 1 meter dan sensor kanan tidak mendeteksi adanya obstacle, maka keluaran sistem adalah stir berbelok ke kanan menghindari obstacle. Pada nomor 9 sampai 12 merupakan percobaan ketika sensor depan dan sensor kanan mendeteksi obstacle pada jarak 5 sampai 1 meter dan sensor kiri tidak mendeteksi adanya obstacle, maka keluaran sistem adalah stir berbelok ke kiri menghindari obstacle.

\section{KESIMPULAN}

Berdasarkan penelitian yang telah dilakukan, didapatkan kesimpulan bahwa metode logika fuzzy yang digunakan untuk memproses input dari sistem pendeteksi objek berhasil meningkatkan tingkat ketelitian dan kehalusan (smoothness) pada Hardware In the Loop mobil listrik. Sistem ini memiliki ketelitian derajat putar steer adalah $5^{\circ}$ dan putaran maksimalnya adalah $30^{\circ}$, sedangkan untuk kecepatan tertinggi roda belakang adalah $15 \mathrm{~km} / \mathrm{jam}$. Penelitian selanjutnya akan diimplementasikan pada mobil listrik.

Tambahan : Terima Kasih kepada Rektor Universitas Sriwijaya yang telah mendukung penelitian ini melalui skema penelitian Saint Teknologi dan Seni tahun 2020 dengan nomor SK: 0684/UN9/SK.BUK.KP/2020.

\section{REFERENSI}

[1] N. D. Van and G. Kim, "Fuzzy Logic and Deep Steering Control based Recommendation System for Self-Driving Car," 2018 18th Int. Conf. Control. Autom. Syst., no. Iccas, pp. 1107-1110, 2018.

[2] B. Dadang Pribadi, H. Widyantara, and Harianto, "Pengendalian Motor DC Brushless Dengan PID pada Robot Penghindar Halangan (Obstacle Avoidance Robot)," Jcones, vol. 3, no. 1, pp. 6169, 2014.

[3] N. Yang and Q. Liao, "Design and simulation for steer-by-wire system based on fuzzy-PID," in Proceedings - 2015 7th International Conference on Intelligent Human-Machine Systems and Cybernetics, IHMSC 2015, 2015, vol. 1, pp. 291294.

[4] Y. Wu, D. Song, Z. Hou, and X. Yuan, "A fuzzy control method to improve vehicle yaw stability based on integrated yaw moment control and active front steering," Proc. 2007 IEEE Int. Conf. Mechatronics Autom. ICMA 2007, vol. 2, pp. 1508-1512, 2007.

[5] G. Zhanfeng, W. Wenjiang, Z. Jianhua, and S. Zhanpeng, "Electric power steering system based on fuzzy PID control," ICEMI 2009 - Proc. 9th Int. Conf. Electron. Meas. Instruments, pp. 34563459, 2009.

[6] M. Restu and S. Bakhri, "Perbandingan Sistem Pengontrolan PID Konvensional dengan Pengontrolan CMAC , Fuzzy Logic dan ANN Pada Water Level Pressurizer," vol. 17, no. 3, pp. 129-141, 2013.

[7] N. Allu, R. S. Sadjad, and F. A. Samman, "Pengendalian Kecepatan Motor Arus Searah Terkendali Jangkar dengan Pengendali PID Tertala Berbasis Perhitungan Nilai Akar Kuadrat Rata-rata," 2017. [Online]. Available: https://id.scribd.com/document/337750476/Jurnal -Tesis-motor-Dc.

[8] L. Ibarra and C. Webb, "Advantages of Fuzzy Control While Dealing with Complex/ Unknown Model Dynamics: A Quadcopter Example," in New Applications of Artificial Intelligence, 2016, pp. 93-121.

[9] P. Albertos, A. Sala, and M. Olivares, "Fuzzy Logic Controllers. Methodology, Advantages and Drawbacks," no. September, 2000.

[10] C. Yuan, L. Chen, S. Wang, and H. Jiang, "M Control of Vehicle Active Suspension and Electric Power Steering System," 2010 Chinese Control Decis. Conf. CCDC 2010, no. m, pp. 45-49, 2010.

[11] K. R. S. Kodagoda, W. S. Wijesoma, and E. K. Teoh, "Fuzzy speed and steering control of an AGV," IEEE Trans. Control Syst. Technol., vol. 10, no. 1, pp. 112-120, 2002. 
Jurnal ECOTIPE, Vol. 8, No.1, April 2021, Hal. 39-46

p-ISSN 2355-5068, e-ISSN 2622-4852

Akreditasi Kemenristekdikti (SINTA 4), SK. No.10/E/KPT/2019

DOI: 10.33019/jurnalecotipe.v8i1.2121

[12] J. George and T. J. Klir, Fuzzy Set Theory: Foundation and Application. New York: PrenticeHall PTR, 1997.

[13] B. Baasandorj, A. Reyaz, P. J. Ho, C. W. Cheol, D. J. Lee, and K. T. Chong, "A mobile robot obstacle avoidance using fuzzy logic and model predictive control," Appl. Mech. Mater., vol. 548549, pp. 922-927, 2014. 